\title{
THE TAXATION OF EMPLOYEE REVENUE FROM THE FRINGE BENEFITS
}

\author{
Paulina Brejdak*
}

\begin{abstract}
The article presents the issues taxation of employee revenue from the fringe benefits by Personal Income Tax. On the one hand, the employee fringe benefits are identified with a defined benefit and on the other with a non-monetary incentive system. However, the benefits give rise to many doubts and controversies. The reasons for this are the lack of legal definition and the lack of their legal directory. Therefore, the views of the judiciary and decisions of tax authorities indicate for example what can be classified fringe benefits.
\end{abstract}

Key words: tax, taxation, fringe benefits, personal income tax, employee

\section{INTRODUCTION REMARKS}

The Personal Income Tax Act ${ }^{1}$ provides for the possibility of obtaining tax revenue from fringe benefits. In doctrine, these employee benefits refers mainly to the aspect of positive motivational influence - the effectiveness of the work performed and the resulting real benefits on the part

* PhD Candidate, John Paul II Catholic University of Lublin, Faculty of Law, Canon Law and Administration, paulina.brejdak@interia.pl

${ }^{1}$ Article 11 (1) of the Act of 26 July 1991 on Personal Income Tax (Journal of Laws of 2016, item 2032, as amended.), here in after referred to as the Personal Income Tax. 
of employees and employers ${ }^{2}$. The benefits are identified with additional complement the basic remuneration ${ }^{3}$.

The basis for receiving fringe benefits is to establish an employment relationship. This should be understood as the specific legal relationship that connects the employee with the employer. It signifies the obligation to perform certain types of work under the direction of the employer and at the place and time designated by him. In addition, the employer is obliged to employ for remuneration with which the employee's income is connected.

According to the tax law income from employment can be the value of other fringe benefits ${ }^{4}$. Unfortunately, there is no legal definition of these benefits. Helpful in interpreting the concept are the decisions of the tax authorities and jurisdiction which create a quasi catalogue. The interpretation of the concept is problematic because the lack of definitions in tax legislation leads to divergences in the application of the law. Moreover, it is a risk for tax authorities and taxpayers in identifying tax obligations ${ }^{5}$. It is assumed that fringe benefits are all legal or economic facts, which result in free (not related to costs or other form of equivalent) increment in the taxpayer's assets that has a concrete financial dimension ${ }^{6}$. It is important to emphasize of the judgment of the Constitutional Court of July 82014 , signature act K 7/13. The Constitutional Court pointed out the basic criteria for taxation of revenue from fringe benefits.

To be able to talk about the employee revenues from fringe benefits must be fulfilled three mandatory conditions. Firstly, the employee has used them voluntarily, he agreed to it. Secondly, the employee has ben-

${ }^{2}$ J. Sokołowski, Klasyfikacja pozapłacowych świadczeń na rzecz pracowników, [in:] Pozapłacowe świadczenia na rzecz pracowników w firmach i instytucjach, S. Lachiewicz, J. Sokołowski (ed.), Bydgoszcz 1999, p. 22; E. Dobrodziej, Pozapłacowe świadczenia pracownicze, Bydgoszcz 2002, p. 7 and next.

${ }^{3}$ A. Piotrkiewicz, Świadczenia pracownicze-zagadnienia podatkowe, Warsaw 2011, p. IX.

${ }^{4}$ Article 12 (1) Personal Income Tax.

${ }^{5}$ M. Poszwa, Identyfikacja i wycena przychodów z nieodpłatnych świadczeń, Prace Naukowe Uniwersytetu Ekonomicznego we Wrocławiu 2012, No. 252, p. 435.

${ }^{6}$ Judgment of the Supreme Administrative Court of 29 October 1999, sign. act I SA/Gd 1290/98, Legalis No. 88674; Resolution of the Supreme Administrative Court of 24 October 2011, sign. act II FPS 7/10, Legalis No. 374540. 
efited in the form of an increase in assets or a loss of expenses. Thirdly, the benefits must be individual and assigned to a particular employee ${ }^{7}$.

\section{THE EMPLOYEE'S FRINGE BENEFITS. SELECTED ISSUES}

The administrative jurisdiction in relation to the medical services packages $^{8}$ was very different ${ }^{9}$. However, two important resolutions of the Supreme Administrative Court ${ }^{10}$ must be presented which unambiguously resolved and unified the issue the taxation of medical packages even before the judgment of the Constitutional Court ${ }^{11}$.

According to arrangements, the value of benefits in the form of medical services packages is employee revenue. Importantly, it is created when the employee receives the opportunity to use the package. Therefore, it does not matter if the employee has actually used the service. This aspect does not affect the tax revenue ${ }^{12}$. As a result, the fact of granting a medical

7 Judgment of the Constitutional Court of 8 July 2014, sign. act K 7/13, Legalis No. 981872; see: P. Brejdak, Glosa do wyroku Trybunału Konstytucyjnego z dnia 8 lipca 2014 r., sygn. akt K 7/13, Roczniki Nauk Prawnych KUL 2016, No. 1, pp. 161-171.

${ }^{8}$ The medical services packages are offered by private health care facilities. They give the possibility of using health care by an employee based on relevant agreements with the employer. They include, for example, easier access to specialist doctors.

${ }^{9}$ For example, according to the judgment of the Voivodeship Administrative Court in Warsaw of 20 August 2008, sign. act III SA/Wa 625/08, Legalis No. 107448 the value of medical services packages did not constituted revenues for employees. On the other hand, in another judgment of the same court of 29 September 2008, sign. act III SA/Wa 1356/08, Legalis No. 110017 issued a month later, stated that such value generates revenue. In addition, in 2006 medical services packages did not constitute income for the employee. The tax authorities issued resolutions mainly on the basis of the guidelines of the Minister of Finance.

${ }^{10}$ Resolution of the Supreme Administrative Court of 24 May 2010, sign. act II FPS 1/10, Legalis No. 232430; Resolution of the Supreme Administrative Court of 24 October 2011, sign. act II FPS 7/10, Legalis No. 374540.

${ }^{11}$ Individual Interpretation of the Director of the Tax Chamber in Poznan of 22 July 2015 r., sign. act DD3.8222.2.312.2015.MCA, https://sip.legalis.pl/document-full. seam?documentId=nfxhizlsfy3tkmjygmytami, [retrieved: 29 October 2017].

${ }^{12} \mathrm{~K}$. Trojanowska, Świadczenia dla pracowników-vademecum płatnika, Warsaw 2012, p. 64. 
services is a real benefit to him in avoiding any expense ${ }^{13}$. The possibility of using the medical services package has a significant financial dimension. It is worth emphasizing that if an employee wanted to use medical services himself, he would have to buy him for a higher amount than the employer. Consequently, the beneficiary receives a specific financial contribution ${ }^{14}$.

The purchase of a medical package is characterized by certain features. They imply the occurrence of fringe benefits received to employees. In this context, there are three main characteristics of a medical services:

- legal events that have a specific financial dimension;

- this is an employee's right;

- this is the consequence of the law, the possibility of free use of the services included in the package ${ }^{15}$.

The Supreme Administrative Court emphasized that, as a consequence, the inclusion of medical package resulted in income. The employer, as a payer is obliged to add to the employee's remuneration paid during the month the value of medical benefits and to pay Personal Income Tax ${ }^{16}$.

The benefit value is equal to the value of the transferred medical service package. Is determined by the price which the employer has actually acquired them. Under the law, the price is a remuneration. The provider is paid for medical services and is not dependent on the amount of benefits received ${ }^{17}$.

In conclusion, the financing of medical service packages by an employer fulfills not only the employee functions, but also important social func-

${ }^{13}$ Judgment of the Supreme Administrative Court of 1 August 2014, sign. act II FSK 1970/12, Legalis No. 1043474.

${ }^{14}$ The answer of the Undersecretary of State in the Ministry of Finance to the No. 17922 interpellation on tax arrears related to the payment by employers to employees of so-called medical packages, http://orka2.sejm.gov.pl/IZ6.nsf/main/36FD413E, [retrieved: 29 October 2017].

${ }^{15}$ Resolution of the Supreme Administrative Court of 24 May 2010, sign. act II FPS 1/10, Legalis No. 232430; resolution of the Supreme Administrative Court of 24 October 2011, sign. act II FPS 7/10, Legalis No. 374540.

${ }^{16}$ Judgment of the Supreme Administrative Court of 8 February 2012, sign. act II FSK 1437/10, Legalis No. 471999.

${ }^{17}$ Individual Interpretation of the Director of the Tax Chamber in Warsaw of 7 September 2011 r., sign. act IPPB1/415-700/11-2/MS, http://interpretacje-podatkowe.org/ swiadczenia-medyczne/ippb1-415-700-11-2-ms, [retrieved: 29 October 2017]. 
tions. Firstly, it contributes to the development of the private sector of medical services, secondly support of public health ${ }^{18}$. However, their weakness is high operating costs, especially in the most advanced and specialized medical services ${ }^{19}$.

Providing employees a business car for private purposes is a benefit for them. Its value qualifies as income from the employment relationship ${ }^{20}$, which employer should add to the „ordinary” employee income ${ }^{21}$. However, that benefit must be a fringe. Therefore, when the use of cars for private purposes is made on the basis of lease agreements no revenue ${ }^{22 .}$ In the context of fringe benefits, employers have raised doubts in determining their value. It was assumed that the value of benefits should be determined, for example, based on the cost of renting as in a professional car rental company ${ }^{23}$.

The Act on facilitating the establishment of a business activity ${ }^{24}$ has introduced a new accounting system for the provision of benefits for the use of corporate cars for private purposes. As a result, the benefits value is determined on a lump sum basis. The amount set depends only on the

18 The answer of the Undersecretary of State in the Ministry of Finance to the No. 19374 interpellation on the need to regulate the issue of taxation of medical services and other free of charge benefits, http://orka2.sejm.gov.pl/IZ6.nsf/main/41CA6849, [retrieved: 29 October 2017].

${ }^{19}$ P. Lenik, Motywatory pozapłacowe, czyli droga do nowej jakości pracowników. Przedsiębiorstwa i administracja publiczna, Warsaw 2012, p. 115.

${ }^{20}$ Individual Interpretation of the Director of the Tax Chamber in Katowice of 26 May 2015, sign. act IBPBII/1/4511-151/15/MK, https://sip.legalis.pl/document-full. seam?documentId=nfxhizlsfy3tkmjxgy2tenq, [retrieved: 29 October 2017].

${ }^{21}$ T. Krywan, Wykorzystanie służbowego samochodu na cele prywatne, [in:] Aspekt kadrowo-podatkowy wykorzystania samochodów służbowych w celach prywatnych. Pytania i odpowiedzi,. A. Bartosiewicz, K. Bogucka and other (ed.), Warsaw 2015, p. 18.

${ }^{22}$ Individual Interpretation of the Director of the Tax Chamber in Katowice of 21 July 2015, sign. act IBPB-2-1/4511-59/15/MK, https://sip.legalis.pl/document-full.seam?documentId=nfxhizlsfy3tkmjygqytony, [retrieved: 29 October 2017].

${ }^{23}$ Individual Interpretation of the Director of the Tax Chamber in Bydgoszcz of 7 January 2015, sign. act ITPB2/415-970/10/12-S/ENB, https://sip.legalis.pl/document-full. seam?documentId=nfxhizlsfy3tambyha2tena, [retrieved: 29 October 2017].

${ }^{24}$ Act of 7 November 2014 on facilitating the establishment of a business activity (Journal of Laws of 2014 item 1662, as amended). 
engine capacity ${ }^{25}$. Moreover, under the law the employer is not obliged to record the course of the car to determine the value of the benefit ${ }^{26}$.

The new rules apply only to accounts of employees who are employed under a contract of employment. In other cases, the value of benefits is determined on the basis of the general rules resulting from the provisions of the Personal Income $\operatorname{Tax}^{27}$. Importantly, there is no income if the vehicle is used only for business purposes ${ }^{28}$. It is important to distinguish between the private purposes of the business. The business purpose is to use a car when an employee performs his obligations resulting from a contract of employment, for example sales representatives. The car is an aid in the effective implementation of its employee duties.

Another a fringe benefit is the use of business telephones for private purposes. This is a form of motivation and attachment of the employee to the company. Today, a business phone is often a mandatory piece of equipment for every employee. Consequently, this affects the availability of the employee and the quality of the work performed ${ }^{29}$.

Due to the possibility of using the phone for private purposes, certain conditions must be fulfilled. The phone must be used for private purposes and the employer does not charge the employee. Which ultimately leads to an individual, personal benefit for the employee. In view of these condi-

${ }^{25}$ Individual Interpretation of the Director of the Tax Chamber in Bydgoszcz of 5 May 2015, sign. act ITPB2/4511-281/15/MU, https://sip.legalis.pl/document-full.seam?documentId=nfxhizlsfy3tkmjyg4zdomy, [retrieved: 29 October 2017].

${ }^{26}$ Individual Interpretation of the Director of the Tax Chamber in Katowice of 5 August 2015, sign. act IBPB-2-1/4511-110/15/MD, https://sip.legalis.pl/document-full. seam?documentId=nfxhizlsfy3tkmjygi3tomi, [retrieved: 29 October 2017].

${ }^{27}$ D. Kosacka, B. Olszewski, Leksykon pracodawcy 2015: prawa i obowiązki pracodawcy od A do Z, Wrocław 2015, p. 460.

${ }^{28}$ Individual Interpretation of the Director of the Tax Chamber in Poznan of 1 September 2011, sign. act ILPB2/415-642/11-2/JK, https://sip.legalis.pl/document-full. seam?documentId=nfxhizlsfy3tambugm4tqnq, [retrieved: 29 October 2017]; Individual Interpretation of the Director of the Tax Chamber in Łodz of 27 September 2012, sign. act IPTPB1/415-376/12-4/ASZ, https://sip.legalis.pl/document-full.seam?documentId=nfxhizlsfy3tamjrga4tcmy, [retrieved: 29 October 2017].

${ }^{29}$ M. Karwiński, Rola motywacyjna składników wynagrodzeń menadżera, Zeszyty Naukowe Uniwersytetu Ekonomicznego w Krakowie 2008, No. 773, p. 117. 
tions, the employer is obliged to fulfill the responsibilities of the payer ${ }^{30}$. In addition, according to the interpretation of the Constitutional Court the employee must voluntarily agree to use the telephone. Also, the employer will be able to determine the extent to which the phone was used for private purposes, even if it was based on billing ${ }^{31}$.

In decisions of the tax authorities co-financing for corrective glasses is fringe of benefits. However, in principle the resulting revenue from them is not subject to tax. In accordance with the Regulation of the Minister of Labor and Social Policy, the employer is obliged to provide corrective glasses with a total of three conditions. Firstly, their use is in line with the doctor's recommendation. Secondly, if the results of the ophthalmic examination indicate the need to use them. Thirdly, the employee must work at the computer monitor ${ }^{32}$. As a consequence, after the fulfillment of these conditions co-financing for corrective glasses is free of Personal Income $\mathrm{Tax}^{33}$.

There are situations where revenue from co-financing for corrective glasses is subject to tax. A necessary condition is a doctor's recommendation, but what is important during optional medical examinations. The employee has the right to request a non-prophylactic examination. In other words, it is a medical examination between mandatory periodic examinations $s^{34}$. If doctor finds a deterioration in vision the employee is entitled

${ }^{30}$ Individual Interpretation of the Director of the Tax Chamber in Katowice of 17 July 2013, sign. act IBPBII/1/415-455/13/MK, https:/sip.legalis.pl/document-full.seam?documentId=nfxhizlsfy3tambxge3dgmi, [retrieved: 29 October 2017].

${ }^{31}$ A. Bartosiewicz, T. Król, R. Styczyński, B. Uzar, Świadczenia pozapłacowe na podstawie opodatkowania, Serwis Prawno-Pracowniczy 2014, No. 46, s. 34.

${ }^{32}$ Section 8 (2) Regulation of the Minister of Labor and Social Policy of 1 December 1998 on occupational safety and health at posts equipped with screen monitors (Journal of Laws No. 148, item 973).

${ }^{33}$ General Interpretation of the Minister of Finance of 16 March 2011, sign. act DD3/033/30/CRS/11/95, https://sip.legalis.pl/document-full.seam?documentId=nfxhizlsfy3tambugaytooa, [retrieved: 29 October 2017].

${ }^{34}$ Individual Interpretation of the Director of the Tax Chamber in Poznan of 10 October 2012, sign. act ILPB1/415-673/12-2/TW, https://sip.legalis.pl/document-full. seam?documentId=nfxhizlsfy3tamjqgy2tenq, [retrieved: 29 October 2017]; Individual Interpretation of the Director of the Tax Chamber in Katowice of 4 April 2012, sign. act 
to purchase corrective glasses with the help of the employer's resources ${ }^{35}$. The result of the medical examination obliges the employer to provide the corrective glasses $^{36}$. In summary, the cost of refund for corrective glasses is additional to the employee. This amount generates income from the employment relationship.

The last example of fringe benefit, which is generated revenue from the employment relationship is additional employee health insurance. This benefit is financed by the employer and is an asset to the employee. Consequently, it is a relief from incurring additional $\operatorname{costs}{ }^{37}$. According to the opinion of the Supreme Administrative Court agreement of medical services packages and agreement of health insurance are the same. Moreover, to ensure medical care in the package is a kind of private health insurance. The most important is the possibility of using medical services, rather than the specific medical services performed by the employee. The employer does not purchase specific services, because at the time of signing the agreement the amount or type of benefits actually realized is not known ${ }^{38}$.

IBPBII/1/415-1063/11/MK, https://sip.legalis.pl/document-full.seam?documentId=nfxhizlsfy3tambzgy3timy, [retrieved: 29 October 2017].

${ }^{35}$ Individual Interpretation of the Director of the Tax Chamber in Łodz of 4 March 2014, sign. act IPTPB1/415-719/13-6/DS, https://sip.legalis.pl/document-full.seam?documentId=nfxhizlsfy3tamjtgy2tooa, [retrieved: 29 October 2017].

${ }^{36}$ Individual Interpretation of the Director of the Tax Chamber in Poznan of 19 March 2015 r., sign. act ILPB2/415-1245/14-2/WS, https://sip.legalis.pl/document-full. seam?documentId=nfxhizlsfy3tkmjyg43tcny, [retrieved: 29 October 2017]; Individual Interpretation of the Director of the Tax Chamber in Warsaw of 10 June 2015, sign. act IPPB4/4511-592/15-2/MS2, https://sip.legalis.pl/document-full.seam?documentId=nfxhizlsfy3tkmjygm2tmoa, [retrieved: 29 October 2017]; Individual Interpretation of the Director of the Tax Chamber in Łodz of 16 July 2015, sign. act IPTPB1/4511-292/15-4/ $\mathrm{MH}, \quad$ https://sip.legalis.pl/document-full.seam?documentId=nfxhizlsfy3tkmjygiytqoi, [retrieved: 29 October 2017]; Individual Interpretation of the Director of the Tax Chamber in Poznan of 19 March 2015, sign. act ILPB2/415-1245/14-2/WS, https://sip.legalis.pl/ document-full.seam?documentId=nfxhizlsfy3tkmjyg43tcny, [retrieved: 29 October 2017].

${ }^{37}$ Resolution of the Supreme Administrative Court of 24 October 2011, sign. act II FPS 7/10, Legalis No. 374540.

${ }^{38}$ Judgment of the Supreme Administrative Court of 8 February 2012, sign. act II FSK 1437/10, Legalis No. 471999. 


\section{THE FRINGE BENEFITS WHICH ARE NOT REVENUE}

According to the law and the case law there are employee benefits which are not taxation by Personal Income Tax.

Among the tax authorities was the view that employee integration events are fringe and taxable by Personal Income Tax. It was emphasized that from a tax point of view the quantity and quality of food or attractions used by an employee is irrelevant. However, in the judgment of most courts where the value of benefits cannot be attributed to a particular person and the fee is paid on a lump sum, it is impossible to determine the amount of income earned from a meeting for an individual employee. There is no basics to conclude the fact that an employee has actually received a service and stated its value ${ }^{39}$. The Constitutional Court's judgment clearly stated that employee integration events do not generate revenue which in consequence would be taxable to income ${ }^{40}$.

On the basis of this judgment changes were made to the views of tax authorities. One of them is an adjustment of the Minister of Finance interpretation's which confirms that integration events are not taxable. Not every the free of charge employee benefits are taxable by Personal Income $\mathrm{Tax}^{41}$.

An example of this is the tasting of meals by the kitchen staff in the school canteen. It cannot be assumed that these persons receive real benefits in the form of meals. The specificity of the occupation requires them to tasting the meals in different stages of their preparation and is an essential part of proper performance of entrusted duties. Thus, there is no income

${ }^{39}$ Judgment of the Voivodeship Administrative Court in Warsaw of 16 June 2009, sign. act III SA/Wa 412/09, Legalis No. 238690; Judgment of the Voivodeship Administrative Court in Poznan of 23 September 2011, sign. act I SA/Po 407/11, Legalis No. 371995; Judgment of the Supreme Administrative Court of 11 January 2011, sign. act II FSK 1531/09, Legalis No. 392016. 981872 .

${ }^{40}$ Judgment of the Constitutional Court of 8 July 2014, sign. act K 7/13, Legalis nr

${ }^{41}$ General Interpretation of the Minister of Finance of 7 January 2016, sign. act DD3.8222.2.330.2015.CRS, https://sip.legalis.pl/document-full.seam?documentId=nfxhizlsfy3tkmrqgmztena, [retrieved: 29 October 2017]. 
from free of charge employee benefits and employers are not obliged to pay the payer in this regard ${ }^{42}$.

In addition, the provision of accommodation by the employer is not taxable. In justifying its decision the Constitutional Tribunal stated that all costs of accommodation, which result from the work performed at the place and time specified by the employer do not generate revenue ${ }^{43}$. In other words, if from employment agreement result that the employee's duties are performed outside of the place of residence is an consequence of the employee revenue does not occur.

The provision of accommodation follows with the consent of the employee, but not in his interest. The Supreme Administrative Court's stated that employees satisfy their housing needs another place. Therefore, they do not receive benefits, the employer incur the $\operatorname{costs}^{44}$.

\section{CONCLUSION}

Taking into account the above that the value of employee fringe benefits could be revenue must be fulfill specific criteria. They were clearly indicated by the Constitutional Tribunal. Thus, not all benefits received from the employer are included in the income from the employment relationship.

Receiving a fringe benefit is not only a motivation problem for the employee but also a concrete financial benefit. From the tax point of view the concept of benefits raises many controversies and doubts. The lack of legal definition on the one hand creates the arbitrary interpretation of the rule. And on the other, it causes the taxpayer's anxiety. Because, the tax-

${ }^{42}$ Individual Interpretation of the Director of the Tax Chamber in Poznan of 21 May 2014, sign. act ILPB2/415-217/14-2/WS, https://sip.legalis.pl/document-full.seam?documentId=nfxhizlsfy3tamjugi4deoa, [retrieved: 29 October 2017].

${ }^{43}$ Individual Interpretation of the Director of the Tax Chamber in Warszaw of 21 July 2015, sign. act IPPB4/4511-634/15-2/MP, https:/sip.legalis.pl/document-full.seam?documentId=nfxhizlsfy3tkmjyg4ytami, [retrieved: 29 October 2017].

${ }^{44}$ Judgment of the Supreme Administrative Court of 19 September 2014, sign. act II FSK 2280/12, Legalis No. 1161429. 
payer is responsible for not paying taxes. Thus, it is exposed to the application of sanctions.

The analysis of the problem shows the inability to classify all fringe employee benefits. The reason for this is too wide and constantly increasing range. In addition, it is difficult to comprehensively identify all the elements and features of employee benefits. Of course, case law and doctrine fills the legal gaps. However, it should be remembered that they cannot create but only apply the law. The role of judicature leads to informal law-making.

The above considerations authorize the submission of several proposals de lege ferenda. It is extremely important to develop a legal definition fringe benefits in order to eliminate doubts and interpretational contradictions. It should be emphasized ever-increasing universality fringe employee benefits. Therefore, it is necessary to create such a tax law that the employee and the employer do not incur excessive tax burdens. And receiving fringe resulted in a specific and individualized benefit. In addition, due to the increasing popularity are expected to more highlight their problems.

\section{REFERENCES}

Bartosiewicz A., Król T., Styczyński R., Uzar B. 2014, Świadczenia pozapłacowe na podstawie opodatkowania, Serwis Prawno-Pracowniczy, No. 46.

Brejdak P. 2016, Glosa do wyroku Trybunału Konstytucyjnego z dnia 8 lipca 2014 r., sygn. akt K 7/13, Roczniki Nauk Prawnych KUL, No. 1, pp. 161-171. Dobrodziej E. 2002, Pozapłacowe świadczenia pracownicze, Bydgoszcz.

Karwiński M. 2008, Rola motywacyjna składników wynagrodzeń menadżera, Zeszyty Naukowe Uniwersytetu Ekonomicznego w Krakowie, No. 773, pp. 111-120.

Kosacka D., Olszewski B. 2015, Leksykon pracodawcy 2015: prawa i obowiązki pracodawcy od A do Z, Wrocław.

Krywan T. 2015, Wykorzystanie służbowego samochodu na cele prywatne, in: Aspekt kadrowo-podatkowy wykorzystania samochodów służbowych w celach prywatnych. Pytania i odpowiedzi,. A. Bartosiewicz, K. Bogucka and other (ed.), Warsaw, pp.17-22; 
Lenik P. 2012, Motywatory pozapłacowe, czyli droga do nowej jakości pracowników. Przedsiębiorstwa i administracja publiczna, Warsaw.

Piotrkiewicz A. 2011, Świadczenia pracownicze-zagadnienia podatkowe, Warsaw. Poszwa M. 2012, Identyfikacja i wycena przychodów z nieodpłatnych świadczeń, Prace Naukowe Uniwersytetu Ekonomicznego we Wrocławiu, No. 252, pp. 432-439;

Sokołowski J. 1999, Klasyfikacja pozapłacowych świadczeń na rzecz pracowników, in: Pozapłacowe świadczenia na rzecz pracowników w firmach i instytucjach, S. Lachiewicz, J. Sokołowski (ed.), Bydgoszcz.

Trojanowska K. 2012, Świadczenia dla pracowników-vademecum płatnika, Warsaw. 